\title{
Method of Teaching and Learning of Higher Education in Ancient India
}

\author{
Tran Thi Ngoc Thu ${ }^{1}$, Tran Van Trung ${ }^{2}$
}

\begin{abstract}
In ancient time Indian organized life of the people as social groups began in the Vedic period. The Vedic people - as their literature suggests were mainly an agricultural people living a settled life. They had their centre mainly in the rural areas where they lived the simple life of farmer and herdsman.

The primitive Aryan society was divided into four varnas or caste with specific duties prescribed for each. Thus, the Brahmins, the highest class were engaged in the pursuit of knowledge, in teaching, in sacrificial and priestly duties. Gradually the Brahmins monopolized higher education and academic pursuits were confined to them only. The Vedic literature naturally formed the main topic of study in this period. Besides the sacred hymns, there were also some historical poems, ballads and hero-songs in existence, which were also committed to memory by the young scholars of the day, as they often helped the elucidation of some references contained in the Vedic hymns. Students were required to master the principles of prosody and encouraged to develop the powers of versification. Vedic studies usually began at about the age of nine or ten and Initiation Ceremony known as Upanayana was performed at their commencement.
\end{abstract}

Keywords - Vedic, Aryan society, varna, caste, Brahmin, priest, hymn, ballad, hero-song,

\section{INTRODUCTION}

Indian Education reached its climax and achieved the highest degree of efficiency and success in this period when it could produce a literature like the Upanishads which are universally admitted to record the utmost possibilities of human speculation regarding some of the ultimate problems of life and metaphysical mysteries. Unfortunately, the evidence on the subject is comparatively meager and not given in any one place in any of the numerous works to be studies for it. One can only find bits of evidence here and there and piece together the scattered bits for constructing a system that may be understood.

\section{Method Of Teaching AND LEARning In ANCIENT INDIA}

Ancient Indian Education was for a long time imparted through the oral lesson, without the medium of a book. This method persisted in the Vedic schools down to recent times. The teacher used to pronounce only two words of the Vedic

Thi Ngoc Thu ${ }^{1}$, 1Research scholar, Department of Education, University of Allahabad, Uttar Pradesh, India,

Tran Van Trung2, M.A student, Department of Social Work, Visva Bharati University, West Bengal, India,

\footnotetext{
${ }^{1}$ Rg-pratisakhya, Patala, XV.

${ }^{1}$ Mil. Pan. I, p. 18.
}

stanza at a time, which the student was asked to recite with exact intonation and accent. The number of words was reduced to one, if the expression happened to be a compound one. ${ }^{2}$ If the student had any difficulty in the matter, it was explained to him. Necessarily every student used to receive individual attention under this system. The method of teaching was direct and personal and not even a text-book intervene the teacher and the student.

The above method of teaching was extensive followed in other branched of learning also, no doubt with suitable modifications, when it was deemed necessary that certain texts should be memorized by the student. It was in this way that students used to learn important books like the grammar of Panini, the dictionary of Amara, the law-book of Manu or the work on poetics by mammata, which had to be committed to memory. Learning in ancient times had to be at the tip of the tongue; a scholar asking for time to consult his notes or books could carry no prestige.

Recitation and recapitulation therefore formed an important part in the daily routine of the student life. The homework, which the student did in his spare time, did not consist of written exercises; it merely amounted to the recitation and recapitulation of lessons learnt already. Every day student was required to spend a part of their time in the school in jointly reciting a portion of the work they had committed to memory. As a result of this training, the memory of the average student in ancient India was very highly developed; he could perform feats of memorizing which now we may regard as impossible.

Ancient Indian educationalists had realized that rhyme makes an appeal to aesthetic sensibility and facilities the task of memorizing. They therefore decided to utilize its help in the teaching work by composing text books in verse. Even dictionaries and elementary books on grammar were composed in verse. The development of the Sutra style, where conclusions are started in short and pithy sentences; is also due to the exigencies of the schools and colleges, the students of which had to rely more on their memory than on books and notes for recalling the contents of the works once studied by them.

Indian teachers were past maters in the art of explanation and exposition; students from distant countries used to brave the dangers of the perilous journey to India, not because they wanted to learn by rote the scriptures of their religion, but because they were anxious to hear the exposition of obscure metaphysical passages which could be heard nowhere else.

\footnotetext{
${ }^{2}$ Rg-pratisakhya, Patala, XV.
} 
Since early times, debates and discussion have always played an important part in the literary training of students. There was a daily examination of every student and no few lessons were given until the old one was thoroughly mastered. ${ }^{3}$ Teachers used to suspend further lessons in the case of those students who were discovered to have forgotten some of the portion done earlier. There were no annual examinations and mass promotions at fixed intervals. The educational system ministered to the need and individual capacity of each student. The intelligent and industrious student could finish his education before the period of time.

It will be seen from the above discussion that the method of teaching followed in Ancient Indian Education System was on the whole the best suited for an age, which did not enjoy the advantages of paper and printing. It developed the powers of memory, a faculty which is being sadly neglected in modern times. Debates were a normal feature of higher education. Individual attention was paid to the needs of students, which naturally ensured good results. The student must however have intelligence. $^{4}$

\section{REFERENCES}

Original Source:

Milindapanho

Ramayana

Rg-Veda-Brahmanas (Aitareya and Kaushitaki)

Rg-Veda-Samhita

Rg-pratisakhya

\section{Secondary Source:}

J. Basu, Indian of the Age of the Brahmanas, Calcutta, 1969.

H.C. Chakladar, Social Life in Ancient India, Calcutta, 1929.

B.C. Law, Early Indian Culture, Calcutta, 1950.

H. Pathak, Cultural History of Gupta Period, Delhi, 1970.

\footnotetext{
${ }^{3}$ Mil. Pan. I, p. 18.

${ }^{4}$ Uttararamacharit, Act II.
} 